\title{
Notonuphar antarctica, an extinct water lily (Nymphaeales) from the Eocene of Antarctica
}

\author{
Else M. Friis ${ }^{1}$ (D) Ari Iglesias $^{2} \cdot$ Marcelo A. Reguero $^{3,4} \cdot$ Thomas Mörs $^{1}$
}

Received: 15 February 2017/ Accepted: 8 April 2017/Published online: 14 June 2017

(C) The Author(s) 2017. This article is an open access publication

\begin{abstract}
A new genus and species, Notonuphar antarctica, is described from the Eocene of Seymour (Marambio) Island, the Antarctic Peninsula and assigned to the Nymphaeales based on well-preserved seeds. This is the first record of a water lily from Antarctica and the first record of a Gondwanan plant with close link to the genus Nuphar (Nymphaeaceae), which is restricted today to the Northern Hemisphere. Critical features for systematic placement of Notonuphar are the presence of a germination cap with closely spaced hilar scar and micropyle, anatropous, bitegmic and exotestal seed organization, exotesta composed of one cell layer of high sclerenchymatic palisadeshape cells, mesotesta of smaller, low parenchymatic cells, a few cell layers deep, and a thin tegmen. The seeds of Notonuphar are particularly similar to seeds of extant and fossil Nuphar in the straight, unfolded anticlinal wall of the exotestal cells and the presence of a narrow zone of exotestal tissue between hilum and micropyle. Other seed features including the very tall exotestal cells and strongly thickened cell walls of exotesta also link Notonuphar to Brasenia and related fossil taxa (Cabombaceae). This
\end{abstract}

Handling editor: Jürg Schönenberger.

Else M. Friis

else.marie.friis@nrm.se

1 Department of Palaeobiology, Swedish Museum of Natural History, Stockholm, Sweden

2 Instituto de Investigaciones en Biodiversidad y Ambiente INIBIOMA (CONICET-UNCO), Quintral 1250,

San Carlos de Bariloche 8400, Rio Negro, Argentina

3 División Paleontología de Vertebrados, Facultad de Ciencias Naturales y Museo, Universidad Nacional de La Plata CONICET, Buenos Aires, Argentina

4 Instituto Antártico Argentino, Buenos Aires, Argentina character mosaic observed in Notonuphar corroborates the transitional position of Nuphar between Cabombaceae and Nymphaeaceae. Notonuphar is the only member of Nymphaeales recorded from Antarctica and so far the only fossil seeds of Nymphaeales known from the Southern Hemisphere. The discovery of this extinct Gondwanan taxon with features suggesting close relationship with extant Northern Hemisphere genus Nuphar is a further evidence for the relictual nature of the extant group.

Keywords Antarctic Peninsula - Basal angiosperms . Fossil seeds · Gondwana - Nuphar P Paleogene

\section{Introduction}

The Nymphaeales include nine genera and about 82 extant species of aquatic herbs in three families, the Hydatellaceae (Trithuria Hook.f.), Cabombaceae (Brasenia Schreb., Cabomba Aubl.) and Nymphaeaceae (Barclaya Wall., Euryale Salisb., Nymphaea L., Nuphar Smith, Ondinea Hartog, Victoria Lindl.). Molecular analyses resolve the group as one of the earliest diverging lineages of angiosperms (Qiu et al. 1999; APG IV 2016), and this basal position is corroborated by the extensive fossil record of Nymphaeales that extends back into the Early Cretaceous (Friis et al. 2001, 2009; Mohr et al. 2008; Taylor et al. 2008; Coiffard et al. 2013; Taylor and Gee 2014).

The present geographic distribution of species reflects the long geological history, and the group is clearly relictual with occurrences that may be difficult to explain based on analyses of the surviving taxa alone (Yoo et al. 2005; Löhne et al. 2008). Nymphaea is almost cosmopolitan (Schneider and Williamson 1993), and Brasenia is distributed in tropical and subtropical regions of both the 
Old and New World with occurrences in North and South America, Africa, India, eastern Asia and Australia. Trithuria is Gondwanan with species in India, Australia and New Zealand, Ondinea is restricted to Western Australia and Victoria restricted to South America; Cabomba occurs in North and South America; Nuphar is widely distributed in temperate regions of the Northern Hemisphere; and Barclaya and Euryale are restricted to eastern Asia (Fassett 1953; Schneider and Williamson 1993; Rudall et al. 2007; Löhne et al. 2008).

The seeds of extant Nymphaeales are all exotestal and bitegmic. Many have a more or less distinct germination cap and many also have strongly undulate anticlinal walls that result in digitate facets on the seed surface. Despite many similarities in seed structure and organization, the nine genera are easily distinguished from each other by morphological and anatomical features of the mature seeds such as size and shape of exotestal and mesotestal cells, thickness of cell walls, surface pattern of the exotestal facets and the position of the hilar scar in relation to the germination cap. Most seeds of Nymphaeales have a hard, sclerenchymatic exotesta, with cubic to high palisade-shaped cells, while in some genera the seed coat is thin. The fossil record of Nymphaeales is based mainly on the occurrences of seeds with a hard seed coat similar to Brasenia, Nuphar, Nymphaea and Euryale (e.g., Kirchheimer 1957; Mai 1964, 1995; Dorofeev 1974; Friis 1985; Gee and Mörs 2001; Chen et al. 2004). In addition to the numerous fossil seeds that can be assigned to extant genera, there are also many fossils assigned to extinct genera of Cabombaceae and Nymphaeaceae based on seed characters (e.g., Miki 1960; Dorofeev 1974; Collinson 1980; Cevallos-Ferriz and Stockey 1989; Taylor et al. 2006; Takahashi et al. 2007). Almost all fossil Nymphaeales are from the Northern Hemisphere, while the Southern Hemisphere record is extremely scarce, currently restricted to compression or impressions of leaves and flowers with the earliest occurrences in the Early Cretaceous Crato Formation of Brazil (Mohr et al. 2008; Coiffard et al. 2013). Here we describe a new extinct genus and species, Notonuphar antarctica, from the Eocene of the Antarctic Peninsula based on wellpreserved seeds. The finding represents the first fossil seeds of Nymphaeales from Gondwana and is remarkable in being most closely related to seeds of Nuphar, but also with unique features in the exo- and mesotesta known only from Brasenia and related fossil taxa. The presence of an extinct relative to the Northern Hemisphere genus, Nuphar, in the Eocene of Antarctica is interesting in emphasizing the relictual nature of the living taxa and may explain difficulties in reconstructing geographic dispersal patterns based on extant species alone.

\section{Materials and methods}

The seeds described here were obtained from marginal marine sediments collected on Seymour (Marambio) Island, Antarctica, during a joint Argentine/Swedish field project during the austral summers 2011-2013. Most of the seeds are from the IAA $1 / 90$ locality (GPS data: $64^{\circ} 14^{\prime} 04.67^{\prime \prime} \mathrm{S} ; 56^{\circ} 39^{\prime} 56.38^{\prime \prime} \mathrm{W}$, Fig. 1) also known as the "Ungulate site" (Marenssi et al. 1998), which is the most productive locality for terrestrial mammals known so far from the fossil record of Antarctica (Chornogubsky et al. 2009). The fossils occur in a conglomeratic lens almost $1 \mathrm{~m}$ thick with a lateral extension of several meters. The lens consists of fine- to coarse-grained sand with pebbles up to $20 \mathrm{~cm}$ in diameter and abundant bioclasts, mainly naticids and belongs to the Cucullaea I Allomember (Telm 5 of Sadler 1988) of the La Meseta Formation (Marenssi et al. 1998). The dating is still unsettled and ranges from early to middle Eocene (51-37 My) depending on the methods used (strontium isotopes; Ivany et al. 2008; paleomagnetism; Montes et al. 2013; dinocysts; Douglas et al. 2014). Locality IAA $1 / 90$ is situated within the Struthiolarella steinmanni zone of Stilwell and Zinsmeister (1992). The second locality yielding Nymphaeales seeds is IAA $2 / 95$ (GPS data: $64^{\circ} 13^{\prime} 58^{\prime \prime} \mathrm{S} ; 56^{\circ} 39^{\prime} 06^{\prime \prime} \mathrm{W}$, Fig. 1) also known as the 'Marsupial site' because of well-preserved marsupial remains. The lithology at this site is also a conglomeratic lens similar to that at IAA 1/90. Due to the dominance of naticid gastropod remains at both sites and similarity in stratigraphic position, the level is informally referred to as the "Natica horizon" (Bomfleur et al. 2015; Schwarzhans et al. 2016).

The seed fossils were concentrated from sediment samples by dry sieving in the field through a $20-\mathrm{mm}$ mesh screens. The concentrate was further dry-sieved in the laboratory at the Museo de La Plata and separated into finer fractions $(>4.0,>2.0,>0.5 \mathrm{~mm})$. The seeds were handpicked from the $>2 \mathrm{~mm}$ fraction using a stereomicroscope.

In total, about 300 seeds representing four different taxa were isolated from the sediments. Seeds assigned to $\mathrm{No}$ tonuphar antarctica described here constitute more than $95 \%$ of all seeds. More complete seeds typically have an outer coalified part (exotesta) and an inner calcified core (inner parts of integuments and remains of nucellus and nutritive tissue), but the calcified core is sometimes found separated from the coalified part of the seed. Six specimens (S 174048-S 17403) were mounted on aluminum stubs, coated with gold and imaged using a Hitachi S-4300 field emission scanning electron microscope at the Swedish Museum of Natural History (images shown here) and a FEI scanning electron microscope from the Servicio de Microscopia at La Plata University. Five specimens 
Fig. 1 Map of the northern Antarctic Peninsula showing the location of Seymour Island and the positions of the two fossil localities IAA $1 / 90$ and IAA $2 / 95$. The oval and arrows indicate the possible region from where the Notonuphar seeds might have been transported into the estuarine sediments preserved at Seymour Island

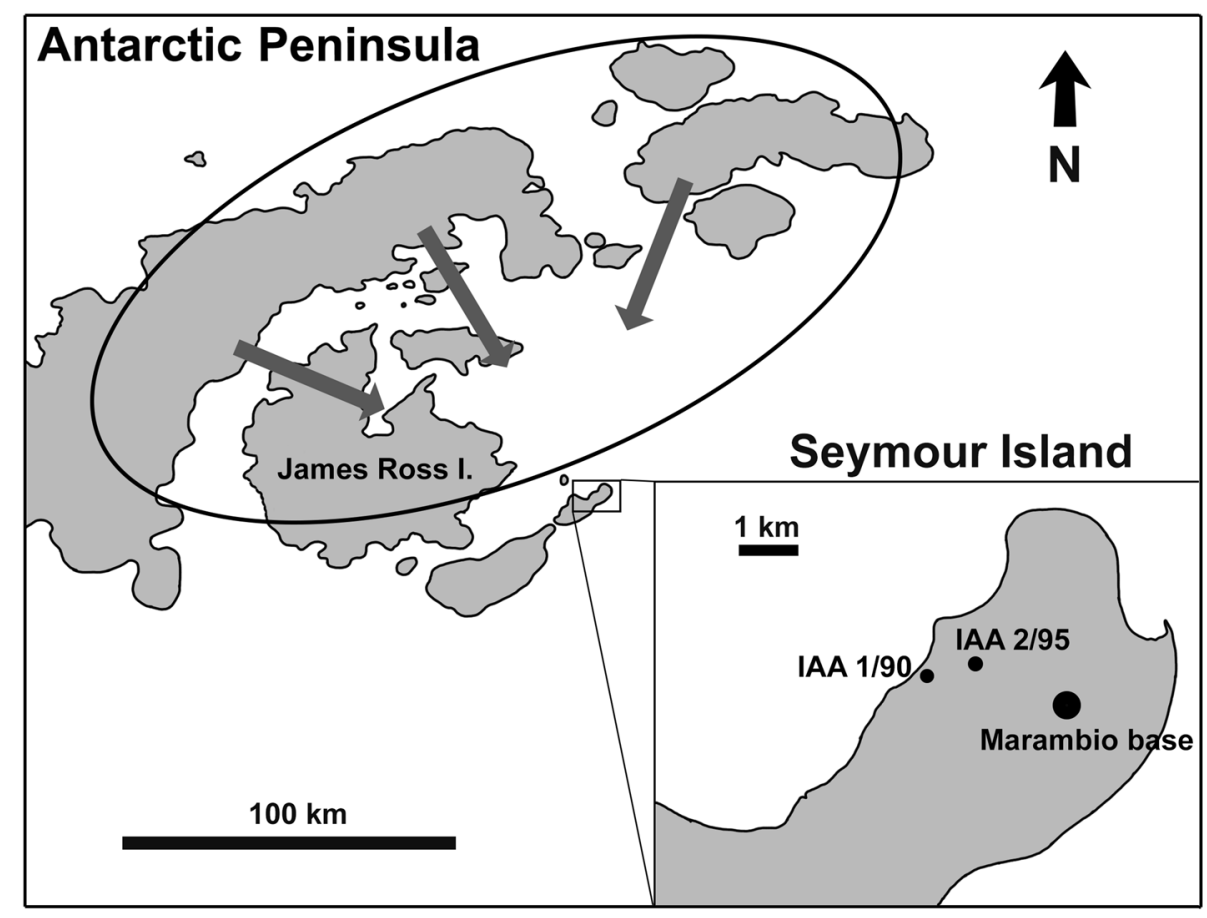

(S 174003, S 174046, S 174047, S 104060, S 174950) were mounted on brass stubs for analyses of internal features using synchrotron radiation-based X-ray tomographic microscopy (SRXTM) at the TOMCAT beamline of the Swiss Light Source at the Paul Scherrer Institute, Switzerland (cf. Stampanoni et al. 2006; Friis et al. 2014). The analyses were performed using $\times 10$ objective with isotopic pixel size of 0.74 and $0.65 \mu \mathrm{m}$ at $20-25 \mathrm{keV}$, a sCMOS detector and a LuAG-20 $\mu \mathrm{m}$ scintillator screen. Structures were then reconstructed from the raw data using Avizo (version 9.1.1) software for computed tomography.

Three specimens (MLP 00-I-1-2a, b, c) were embedded in resin, sectioned and polished for thin sections following routine preparation for petrographic slides. Thin sections were observed under transmitted light and epifluorescence microscopes at the INFIVE (Instituto de Fisiología Vegetal, La Plata University). Stacking of pictures was done at $40 \times$ and $60 \times$ with a BX40 Olympus microscope with a green filter (exciter 66501; emitter 116326 Chroma Technology Corp.).

To test the most likely position of Notonuphar among extant genera of Nymphaeales, we performed a simple mapping of the seed characters (Table 1) on a phylogenetic backbone tree of Nymphaeales and calculated tree lengths for different positions of Notonuphar along the tree. As backbone tree, we used the tree of Les et al. (1999) derived from a combined molecular and morphological data analysis and added Trithuria. Ancestral states were reconstructed using the Ancestral State Reconstruction Package implemented in Mesquite (Maddison and Maddison 2011)
Table 1 Seed characters of extant genera of Nymphaeales and fossil Notonuphar antarctica

\begin{tabular}{llllllllllll}
\hline $\begin{array}{l}\text { Taxa/ } \\
\text { characters* }\end{array}$ & 1 & 2 & 3 & 4 & 5 & 6 & 7 & 8 & 9 & 10 & 11 \\
\hline Trithuria & 0 & 0 & 0 & 0 & 0 & 1 & 0 & 0 & 0 & 1 & 0 \\
Cabomba & 0 & 0 & 0 & 0 & 0 & 0 & 0 & 0 & 0 & 0 & 0 \\
Brasenia & 0 & 0 & 0 & 0 & 0 & 0 & 1 & 1 & 1 & 1 & 1 \\
Nuphar & 0 & 0 & 0 & 1 & 0 & 1 & 0 & 0 & 1 & 12 & 0 \\
Barclaya & 1 & 0 & 0 & 1 & 0 & 0 & 0 & 0 & 0 & 0 & 0 \\
Ondinea & 0 & 1 & 1 & 1 & 0 & 0 & 0 & 0 & 0 & 1 & 0 \\
Nymphaea & 0 & 1 & 0 & 1 & 0 & 0 & 0 & 0 & 0 & 1 & 0 \\
Victoria & 0 & 1 & 1 & 1 & 0 & 0 & 0 & 0 & 1 & 1 & 0 \\
Euryale & 0 & 1 & 1 & 1 & 1 & 1 & 0 & 0 & 2 & 1 & 0 \\
Notonuphar & 0 & $?$ & 0 & 1 & 0 & 1 & 1 & 1 & 1 & 0 & 0 \\
\hline
\end{tabular}

* 1 Ovule; anatropous: 0; orthotropous: 1.2 Aril; absent: 0; present: 1 . 3 Micropyle integuments; inner: 0; inner and outer: 1. 4 Testa between micropyle-hilum; absent: 0; present: 1. 5 Seed coat; exotestal: 0; exotestal-mesotestal: 1. 6 Facets of exotesta; undulate: 0; straight: 1. 7 Exotestal cells; low: 0; high: 1. 8 Exotestal cell walls; thin: 0; thick: 1.9 Depth of mesotesta: up to 3 cell: 0 ; up to 5 cell: 1 ; more than 5: 2. 10 Seed surface; spiny: 0; smooth: 1; hairy: 2. 11 lumen; straight: 0 ; conical: 1

with all characters treated as unordered. Only seed characters were included in the matrix.

The specimens are housed in the Swedish Museum of Natural History, Department of Palaeobiology, Stockholm (S) and the repository of the Museo de La Plata (MLP), Buenos Aires, Argentina. 


\section{Results}

\section{Description of the fossil seeds}

Almost 285 seeds and fragments of seeds were extracted from the sediments. Entire seeds typically have a coalified (lignitized) outer seed coat and a calcified inner core comprising the mesotesta, endotesta, tegmen and the inner seed tissues. Fragments may comprise part of the coalified seed coat attached to the calcified core or parts of the coalified seed coat and the calcified core may occur isolated.

The seeds are anatropous, bitegmic and exotestal, ovoid to ellipsoid and almost circular in cross section, about 2.0-2.3 mm long and 1.5-1.8 mm broad (Figs. 2, 3) with a distinct germination cap, about $0.6 \mathrm{~mm}$ in diameter, at the micropylar end of the seed (Figs. 2, 3a, d). The germination cap is oblique conical with a rounded base (Figs. 2a-f, $3 \mathrm{a}, \mathrm{d})$ and is mainly formed by the outer integument. The micropyle is formed from the inner integument, but the micropylar operculum is not distinct as it is in seeds of many extant Nymphaeaceae. The micropylar opening in the outer integument is slit-like at the top of the germination cap surrounded by exotestal cells (Fig. 2h). Next to the micropyle on the germination cap is a distinct shallow hilar scar with an uneven surface (Figs. 2a, b, d, 3a, d). Micropyle and hilar scar are separated by a narrow zone of exotestal cells (Figs. 2f-i, 3d). In most specimens the germination cap is detached leaving an almost circular opening in the exotesta flanked by the high palisade-shaped cells (Figs. 3b, c, 4c).

Exotesta consists of one layer of palisade-shaped sclerenchyma cells, about $0.21 \mathrm{~mm}$ thick over most of the seed and about $0.14 \mathrm{~mm}$ in the micropylar and chalazal regions. The exotestal cells have thick anticlinal walls that leave only a narrow space for the elongate lumen (Figs. 2f, g, 3c, 4a-d). The anticlinal walls are straight, unfolded and equally thickened for the full high of the exotestal cell leaving an elongated, narrow lumen (Fig. 4a, b). The cell walls lack undulations resulting in polygonal (pentagonal to hexagonal) and isodiametric facets (Fig. 2f) that are particularly distinct in the region of the germination cap (Figs. 2d, h, 3d, e). The exotesta surface is smooth, and the seeds were apparently exarilate. The mesotesta is much thinner than the exotesta, about $0.05 \mathrm{~mm}$ thick, and consists of low, rectangular and thin-walled parenchyma cells. The mesotesta is a few cells deep over most of the seed (Figs. 3b-d, 5b), but slightly thicker along the raphe and near the chalazal and micropylar ends (Figs. 4c, 5a). Mesotesta appears to separate easily from the exotesta (Figs. 4a-d, 5) and, probably because of the thin cell walls, the mesotesta is mostly calcified together with the tegmen
Fig. 2 Notonuphar antarctica gen. et sp. nov, from the Eocene of Seymour Island, Antarctica; SRXTM volume renderings of seeds. a Holotype; lateral view of seed showing outer smooth surface of exotesta and germination; hilum (hi) and micropyle (mi) are close to each other on the germination cap (S 174950; IAA 2/95, Marsupial site). b, c Lateral views of seed with exotesta partly broken off exposing the inner calcified core lined by mesotesta and tegmen; note the distinct raphe on the inner core (S 174046; IAA 1/90, Ungulate site). d Apical view of holotype in Fig. 2a showing germination cap with closely spaced hilum (hi) and micropyle (mi). e Apical view of seed with part of exotesta and germination cap preserved; note tall and thick-walled cells exotesta and the thin layer of mesotesta between exotesta and tegmen (S 174003; IAA 1/90, Ungulate site). f, g Volume renderings cut through the micropylar (mi) and hilar (hi) area of seed shown in (e) in angles perpendicular to each other; mesotesta is thicker close to the micropyle (f cut at orthoslice yz1443; g cut at orthoslice xz1253). h, i Volume renderings transversely cut through the micropylar (mi) and hilar (hi) area of seed shown in (e) at two different levels, $\mathbf{h}$ close to the apex and $\mathbf{i}$ further down; note narrow zone of exotestal cells (asterisk) between micropyle and hilum/raphe (h cut at orthoslice xy0300; $\mathbf{i}$ cut at orthoslice xy0510). Scale bars $1 \mathrm{~mm}(\mathbf{a}-\mathbf{c}), 0.5 \mathrm{~mm}(\mathbf{d}-\mathbf{i})$

and other internal tissues. The distinction between mesotesta and tegmen, as well as between tegmen and nucellus, is not always clear, except near the seed apex where tegmen is extended into the micropyle (Fig. 2f). In some specimens, the nucellus also appears to have an apical protuberance. None of the five specimens studied using SRXTM show details of internal features such as embryo, endosperm or perisperm.

The position of the raphe is indistinct on the seed surface (Fig. 2a), but in the calcified cores the raphe is seen on the surface of mesotesta as a slightly raised, rounded ridge running from the hilar area to chalaza (Fig. 2b) and the raphe canal is distinct between exotesta and tegmen (Figs. 4d, 5a).

\section{Discussion}

\section{Systematic affinity}

Seed morphology and anatomy clearly place the fossil seeds from Antarctica in the Nymphaeales. However, the seeds differ in several features from those of all other nymphaealean genera described so far and we therefore assign the fossils to a new genus and species, Notonuphar antarctica. Seeds of Nymphaeales are all exotestal (although Euryale is exotestal-mesotestal), bitegmic and usually anatropous (Barclaya, however, is orthotropous). Some seeds have a distinct germination cap where the micropyle and sometimes also the hilar scar are placed. The extant taxa of Nymphaeales are easily distinguished from each other based on seed characters such as shape and 

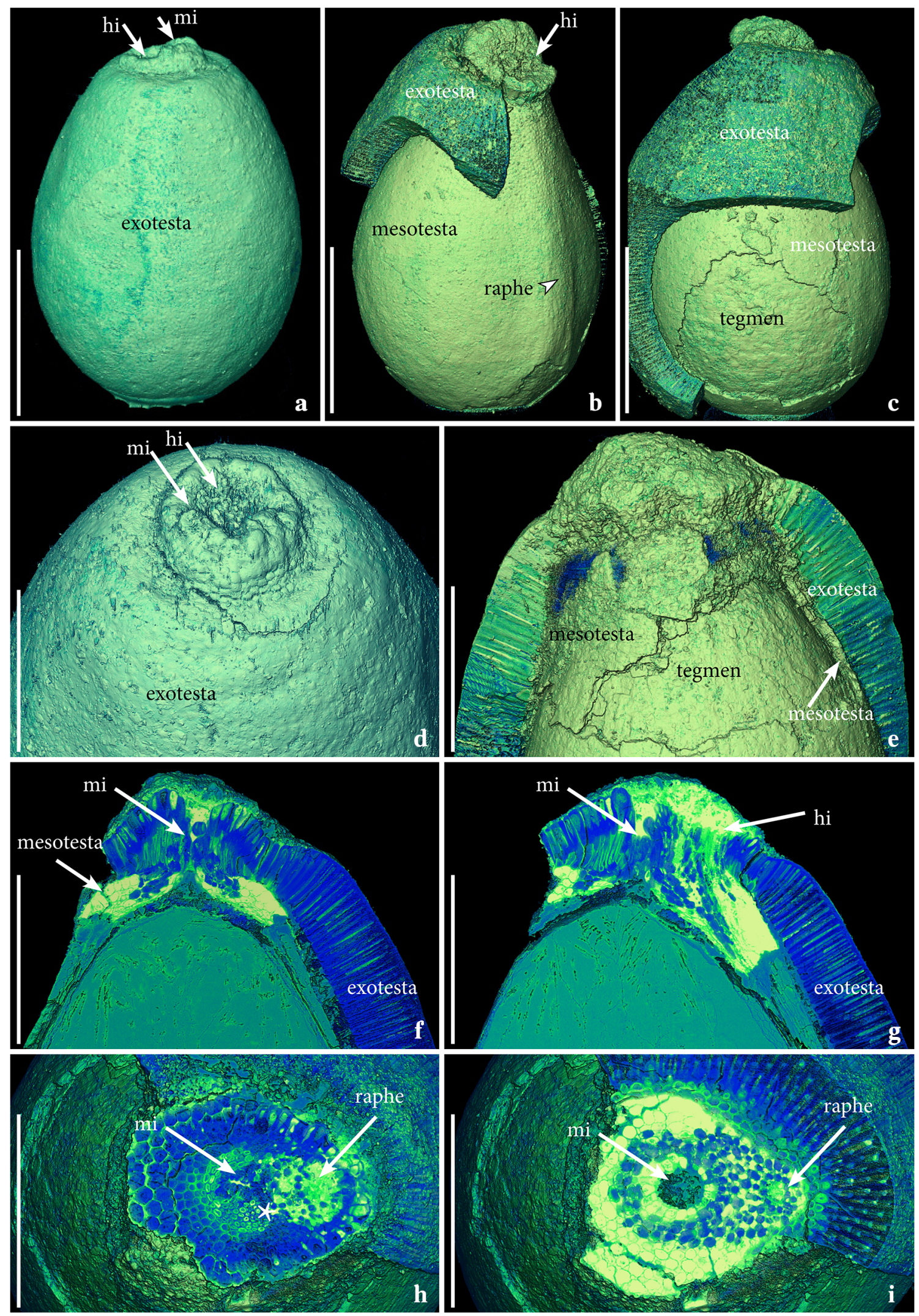

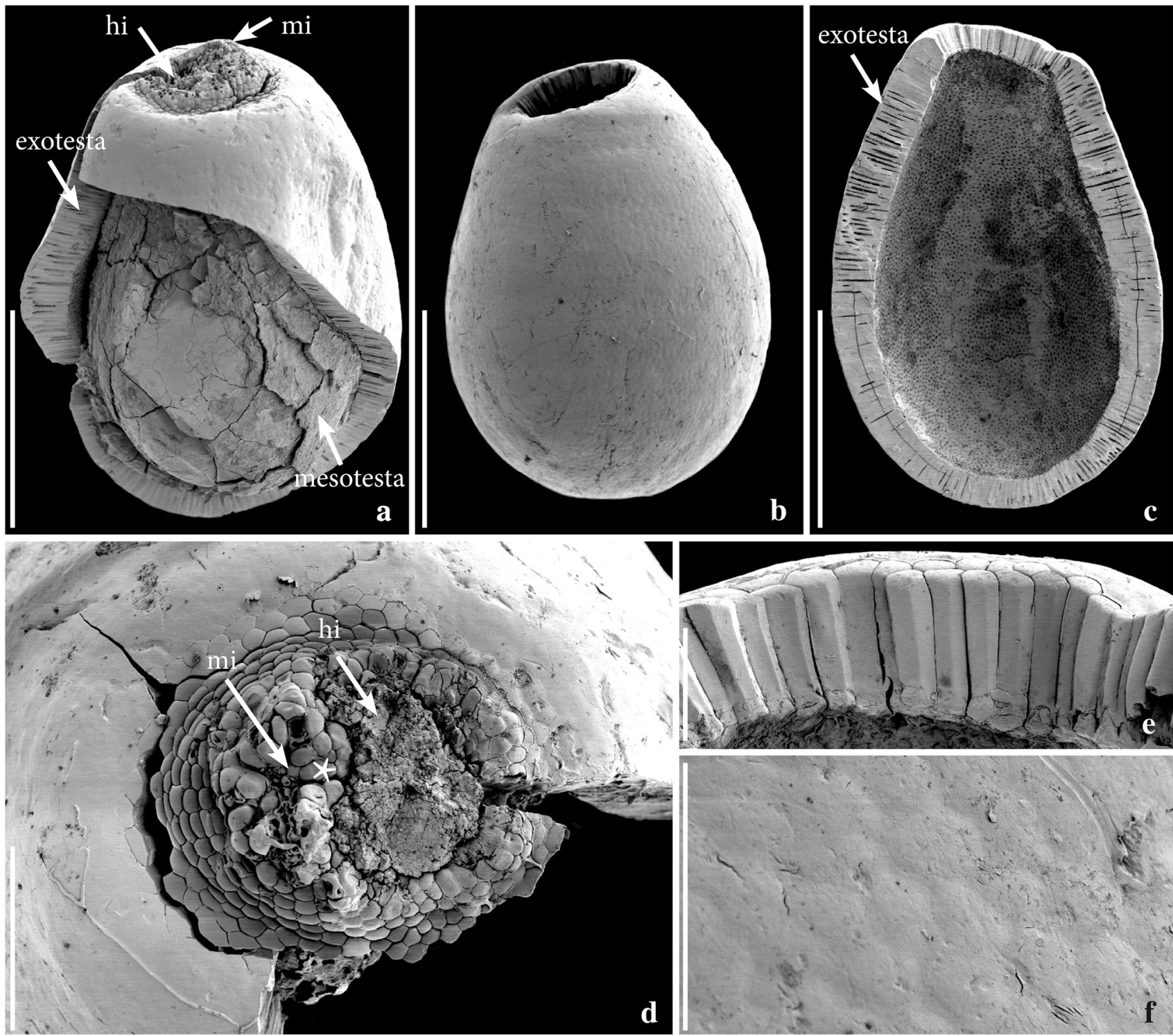

d

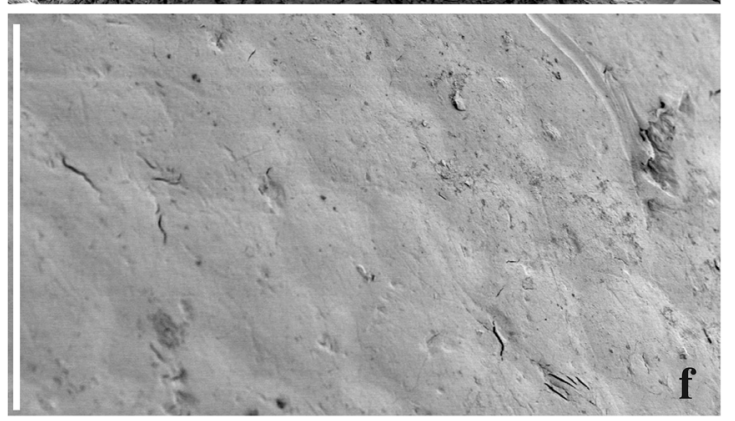

Fig. 3 Notonuphar antarctica gen. et sp. nov, from the Eocene of Seymour Island, Antarctica; SEM images of seeds. a Seed with germination cap and partly preserved exotesta exposing the inner calcified core of the seed with remains of the thin mesotesta; micropyle (mi) and hilum (hi) closely spaced on germination cap (S 174048; IAA 2/95, Marsupial site). b Seed showing the smooth outer surface of the exotesta; germination cap is lost leaving a round opening at the top of the seed (S 174049; IAA 2/95, Marsupial site). c Broken seed with only testa preserved showing the tall palisadeshaped cells of exotesta with narrow cell lumen (S 104052; IAA 2/95,

size of the exo- and mesotestal cells, the proportion between exotesta and mesotesta and the position of the hilar scar in relation to the micropyle (Dorofeev 1974; Collinson 1980; Yamada et al. 2001). These features have also been useful in recognizing extinct genera of Nymphaeales based on fossil seeds. This was demonstrated in early works by Miki (1960) and Dorofeev (see compilation in Dorofeev 1974) in their studies of Cenozoic seeds from
Marsupial site). d Apical part of broken seed with germination cap preserved; note the closely spaced micropyle (mi) and hilum (hi) on the germination cap separated only by a narrow zone of exotestal cells (asterisk); polygonal facets of exotestal cells distinct around and on the germination cap (S 174050; IAA 2/95, Marsupial site). e Palisadeshaped cells of exotesta bordering the germination cap showing the straight, unfolded anticlinal walls and polygonal outer facets; same specimen as c. f Surface view of seed shown in (b) showing faint outlines of the polygonal facets of the exotesta cells. Scale bars $1 \mathrm{~mm}$ $(\mathbf{a}-\mathbf{c}), 0.25 \mathrm{~mm}(\mathbf{d}), 0.1 \mathrm{~mm}(\mathbf{e}, \mathbf{f})$

Japan and the former Soviet Union, respectively. Dusembaya P.I.Dorof. and Braseniella P.I.Dorof. placed in the Cabombaceae and Eoeuryale Miki, Irtyshenia P.I.Dorof., Nikitinella P.I.Dorof., Palaeoeuryale P.I.Dorof., Pseudoeuryale P.I.Dorof. and Tavdenia P.I.Dorof. placed in the Victoria-Euryale group (Nymphaeaceae) are all extinct genera recognized in these early works. Later, Collinson (1980) compiled the results of Miki and Dorofeev and used 

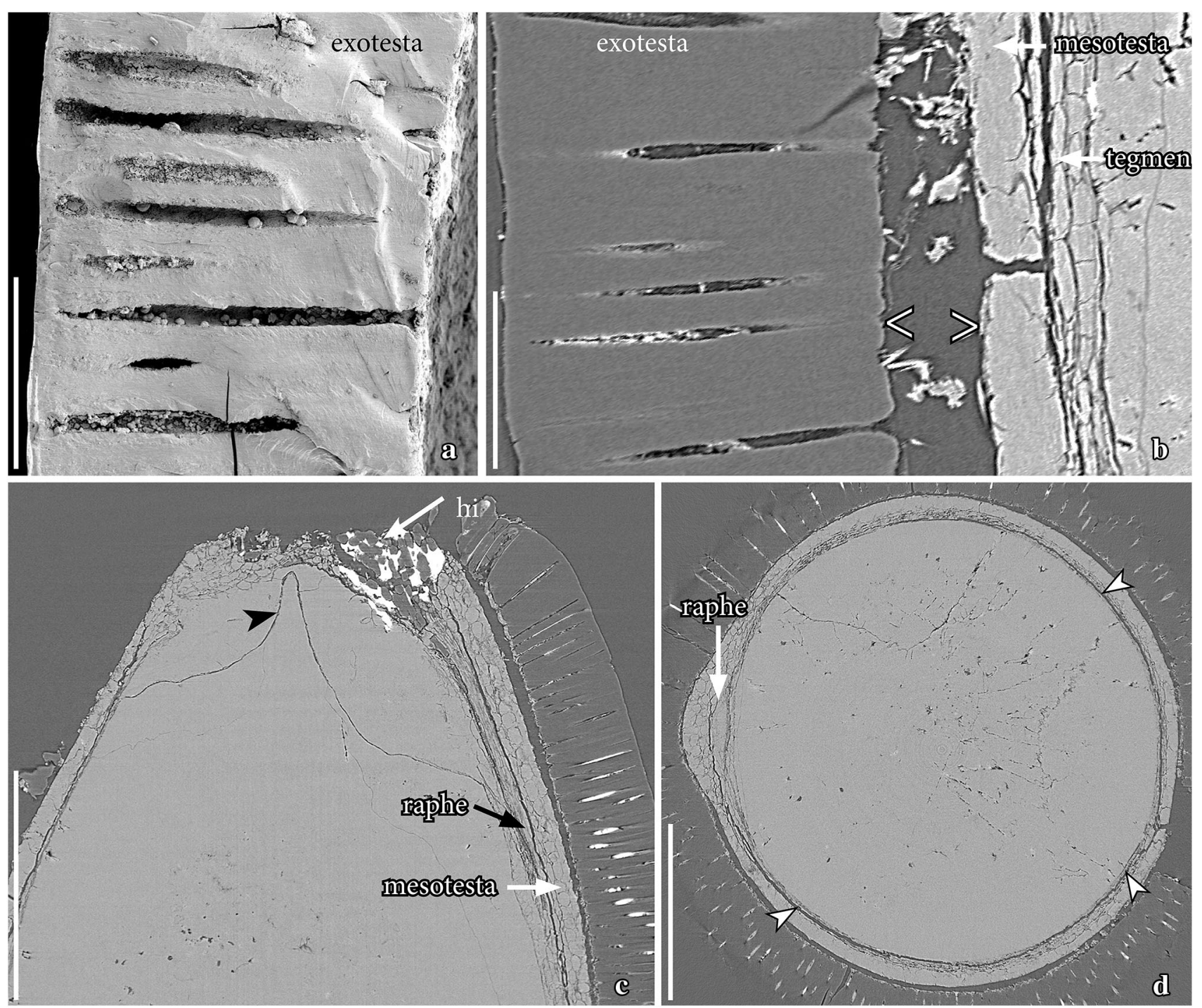

Fig. 4 Notonuphar antarctica gen. et sp. nov, from the Eocene of Seymour Island, Antarctica; SEM (a) and SRXTM orthoslices (b-d). a Exotesta from broken seed in longitudinal view showing the strongly, but evenly thickened and unfolded cell wall (S 104052; IAA 2/95, Marsupial site). b Longitudinal section through testa and tegmen showing the tall, thick-walled coalified cells of exotestal cells and thin, calcified cells of mesotesta and tegmen; exotesta and mesotesta are separated leaving an empty space $(<>)$ (orthoslice yz1357; S 174003; IAA 1/90, Ungulate site). c Longitudinal section

the same features to describe a further extinct genus, Sabrenia M.E.Collinson, of the Cabombaceae. Additional extinct genera such as Symphaeale Ma.Takah., P.R.Crane \& E.M.Friis with features of both Brasenia and Nymphaeaceae, Allenbya Cevallos-Ferriz \& Stockey assigned to the Nymphaeaceae and Susiea Witt Taylor, DeVore \& Pigg closely related to Euryale, were established also based on seed characters. Yamada et al. (2001) also noted differences in the development of the integuments in Cabombaceae and Nymphaeaceae resulting in anatomical differences in the micropylar-hilar area of the mature seeds of seed through raphe region showing cells of exotesta, mesotesta and tegmen and slightly folded pointed apical part of nucellus (black arrowhead); exotesta coalified and inner core of seed calcified (orthoslice xz1450; S 174047; IAA 1/90, Ungulate site). d Cross section of same seed as shown in (c) showing the cell layers of testa and tegmen; exotesta clearly separated from mesotesta; mesotesta and tegmen closely packed, but distinct (white arrowheads) (orthoslice xy2400). Scale bars $0.1 \mathrm{~mm}(\mathbf{a}, \mathbf{b}), 0.5 \mathrm{~mm}(\mathbf{c}, \mathbf{d})$

with a zone of exotestal cells separating micropyle and hilum in Nymphaeaceae, but lacking in this position in Cabombaceae. In Nuphar, the separating exotestal tissue is very narrow, which according to Yamada et al. (2001) reflects an intermediate developmental stage of the integuments between Cabombaceae and Nyphaeaceae.

The fossil seeds of Notonuphar share particularly many features with seeds of Brasenia and Nuphar. This is also evident by a simple mapping of the characters on a phylogenetic backbone tree of Nymphaeales and calculating tree lengths for different positions of Notonuphar along the 

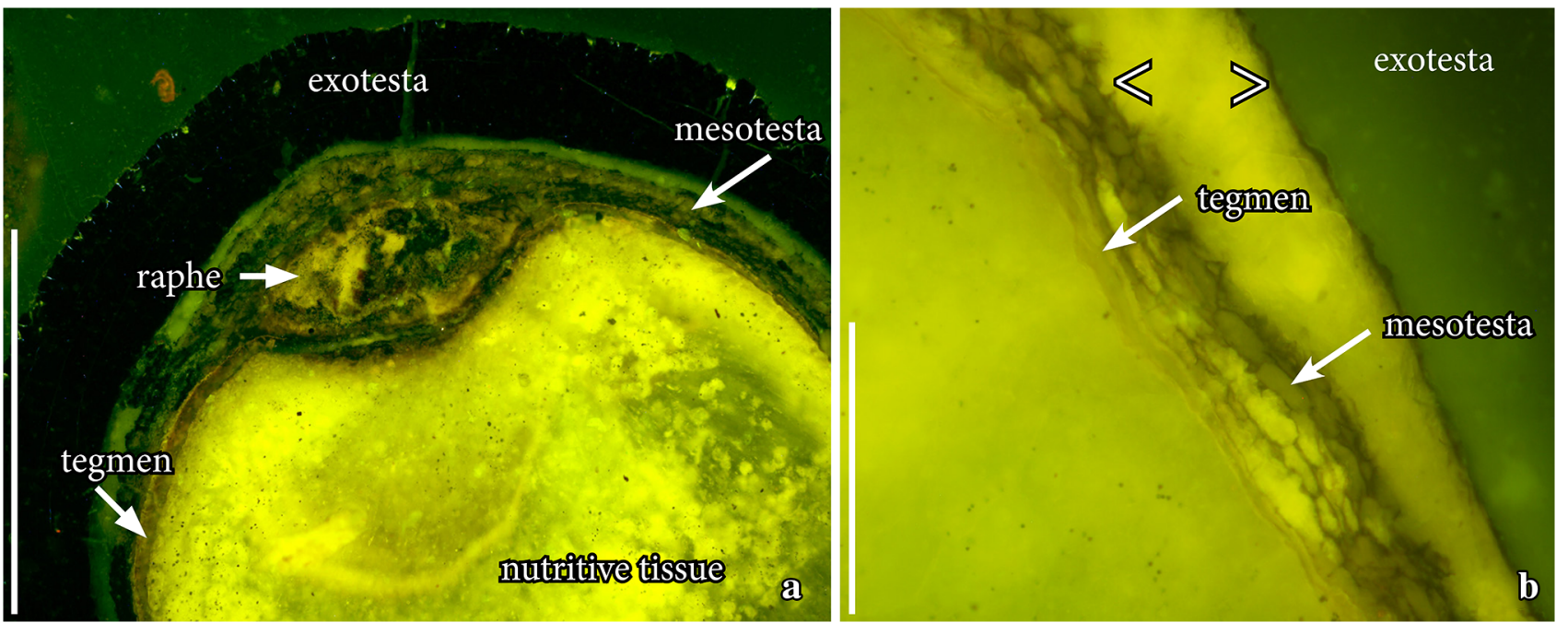

Fig. 5 Notonuphar antarctica gen. et sp. nov, from the Eocene of Seymour Island, Antarctica; fluorescence microscopy images of thin sections of seeds. a Cross section through middle part of seed showing the cells of the raphal area as well as testa and tegmen; faint outlines of nutritive tissue is seen in the inner calcified core of the

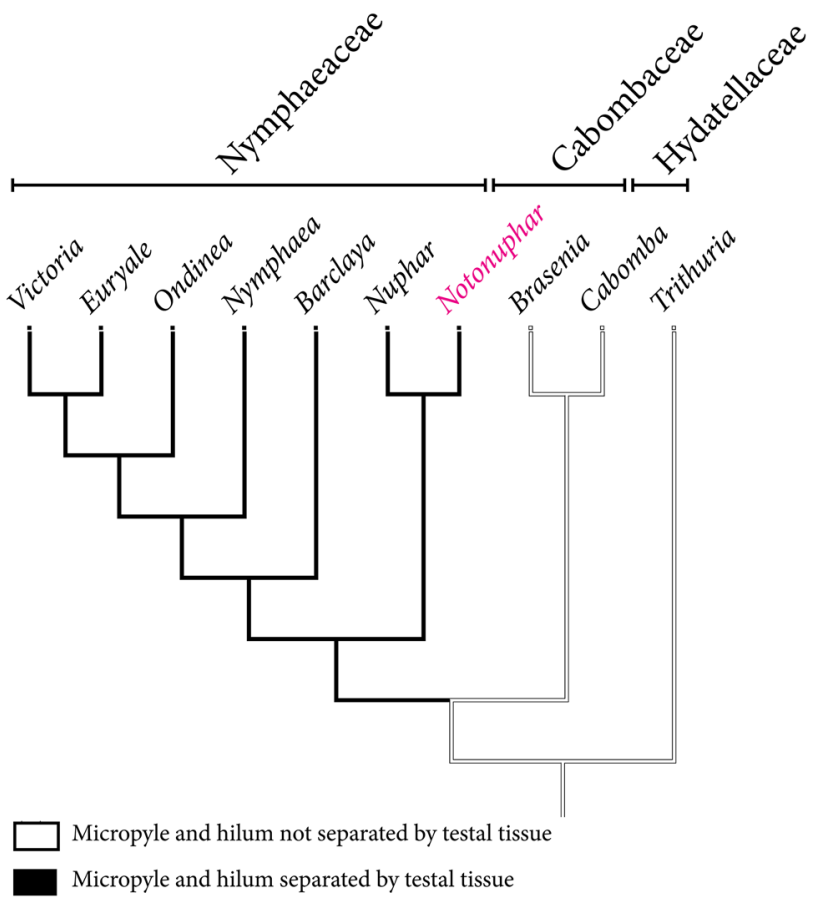

Fig. 6 Most likely position of Notonuphar based on character mapping along a phylogenetic tree of extant genera of Nymphaeales (based on Les et al. 1999). Separation of micropyle and hilum by testal tissue is a feature uniting Notonuphar with Nuphar and other genera of the Nymphaeaceae

tree (Fig. 6). We used the tree of Les et al. (1999) derived from a combined molecular and morphological data analysis and added Trithuria. This tree is in accordance with those generated by later analyses (e.g., Borsch et al. seed (MLP 00-I-1-2a; IAA 1/90, Ungulate site). b Longitudinal section of seed showing procumbent mesotesta cells, a thin tegmen and space between exotesta and mesotesta $(<>$ ) (MLP 00-I-1-2b; IAA 1/90, Ungulate site). Scale bars $1 \mathrm{~mm}(\mathbf{a}), 0.2 \mathrm{~mm}(\mathbf{b})$

2007, 2008; Taylor and Gee 2014) showing Cabombaceae as monophyletic and sister to Nymphaeaceae. Nuphar and Barclaya are successive sisters to core Nymphaeales consisting of Ondinea, Nymphaea, Victoria and Euryale. Seed characters considered are shown in Table 1.

Based on seed characters, a position for Notonuphar either as sister to Brasenia or to Nuphar is equally parsimonious. The seeds of Notonuphar are similar to seeds of extant and fossil Brasenia in having an exotesta of very high sclerenchymatic palisade-shaped cells with strongly thickened anticlinal cell walls and restricted lumen. Mesotesta is in both taxa very thin compared to the exotesta. Both have a small conical germination cap with closely spaced micropyle and hilum. Fossil seeds assigned to extinct genera of Cabombaceae such as Dusembaya, Braseniella and Sabrenia have the same general organization and thick exotesta as in Brasenia. They consistently differ, however, from the seeds of Notonuphar by having strongly folded anticlinal cell walls near the seed surface resulting in digitate facets in contrast to the unfolded walls and polygonal facets of Notonuphar. Brasenia and its fossil relatives also differ from Notonuphar in having uneven thickenings of the anticlinal cell walls of exotesta with walls thinner toward the inside resulting in a conical shape of the cell lumen in contrast to the evenly thickened anticlinal cell walls and narrow, straight lumen of Notonuphar. Another important feature that distinguishes Brasenia and relatives from Notonuphar is the lack of exotestal tissue between micropyle and hilum indicating differences in the development of the integuments as suggested by Yamada et al. (2001). In this respect, the seeds of Notonuphar are 
more similar to those of Nuphar. Both Notonuphar and Nuphar have a narrow zone of exotestal tissue between the micropyle and hilum suggesting similar development of integuments in the two genera. This feature is suggested as important in distinguishing Cabombaceae and Nymphaeaceae and we therefore place Notonuphar in the Nymphaeaceae. Another important feature shared between the seeds of Notonuphar and Nuphar is the straight, unfolded anticlinal walls of the exotestal cells and the smooth outer seed surface with faint outlines of the equiaxial and polygonal facets. Such exotestal cells are otherwise known in the Nymphaeales only for Euryale and its fossil relatives, Eoeuryale, Irtyshenia, Nikitinella, Palaeoeuryale, Pseudoeuryale, Suseia and Tavdenia, but they all have much thinner exotesta and much thicker, sclerotic mesotesta that in Euryale is up to 20 cells deep. Euryale and its relatives are also distinguished from $\mathrm{No}$ tonuphar and Nuphar in having the hilar scar widely separated from the micropyle. Main differences between the Notonuphar and Nuphar seeds is the shallower exotestal cells and much thinner anticlinal cell walls of exotesta in Nuphar resulting in larger cell lumen. In Nuphar, the hilum scar may also be larger than in Notonuphar and placed partly outside the germination cap.

\section{Palaeoecology}

The La Meseta Formation on Seymour (Marambio) Island defines a steep-sided valley fill containing estuarine, deltaic and shallow-marine sediments (Stilwell and Zinsmeister 1992; Marenssi et al. 1998, 2002; Marenssi 2006) in the James Ross back-arc basin (Elliot 1988). The formation is divided in six allomembers (Marenssi et al. 1998) with each member representing a fluvial erosional surface reshaped during following marine transgressions (Marenssi 2006). The discontinuous shell lenses of the "Natica horizon," where the seeds of Notonuphar antarctica were found, are interpreted as the remnants of shifting tidal channels in an estuarine environment (Stilwell and Zinsmeister 1992; Marenssi et al. 1998). The faunal content of the seed-bearing "Natica horizon" is dominated by marine molluscs (Stilwell and Zinsmeister 1992), sharks and other chondrichthyans (Long 1992; Kriwet 2005; Engelbrecht et al. 2016a, b) as well as marine teleost fishes (Schwarzhans et al. 2016). Most of the terrestrial animal remains known from the La Meseta Formation were also collected from the lenses of the "Natica horizon" although they are rare compared to the marine fossils. Mammalian teeth document that gondwanatheres, marsupials and ungulates inhabited the terrestrial realm of the Antarctic Peninsula (for references see Gelfo et al. 2015). Bird bones recovered from the "Natica horizon" document mainly penguins, but also other marine and continental birds: falconids, flamingos and other charadriiforms, albatrosses and other procellariids and ducks (for references see Tambussi and Acosta Hospitaleche 2007). The only animal remains that might indicate freshwater environments are cocoons of clitellates (Mcloughlin et al. 2016). Based on spermatozoa preserved in the cocoon walls, Bomfleur et al. (2015) suggested that the cocoons were possibly produced by branchiobdellids (crayfish worms), a clade that is now restricted to Northern Hemisphere freshwater environments.

Although Notonuphar is represented by seeds only, the close similarity to Nuphar suggests that Notonuphar was an aquatic herb that grew in inundated, freshwater habitats similar to extant Nuphar (Padgett 2007). Thus, Notonuphar is the first reliable indicator for Antarctic freshwater biota. A freshwater habitat is also indicated by seeds closely resembling Nelumbo Adans. that were found co-occurring with Notonuphar (Iglesias and Reguero 2012), but these remain to be documented in detail.

The abundance of Notonuphar seeds at two separated localities indicates that Notonuphar was probably a common plant in the wetlands close to the coast. The fossil seeds were most likely washed into the marine basin together with the clitellate cocoons and mammalian remains by rivers from the Antarctic Peninsula (Fig. 1). The seeds are partly coalified and partly permineralized (calcified) and most likely fossilized post-depositional in the marine sediments.

\section{Notonuphar and other fossil Nymphaeales}

The Nymphaeales have a long fossil history with scattered records through the Early and Late Cretaceous (Takahashi et al. 2007; Mohr et al. 2008; Taylor et al. 2008; Friis et al. 2009; Coiffard et al. 2013) documenting that the group was geographically widespread and systematically diverse already by the Aptian-Albian. Two of the early forms, Monetianthus E.M.Friis, K.R.Pedersen, von Balthazar, G.W.Grimm \& P.R.Crane from the Early Cretaceous Vale de Água mesofossil flora of Portugal (Friis et al. 2009, 2011) and Jaguariba wiersemana Coiffard, B.A.R.Mohr \& Bernardes-de-Oliveira from the Crato macrofossil flora of Brazil (Coiffard et al. 2013) could be assigned to the Nymphaeaceae with great confidence. However, the major diversification of the group with the first occurrence of extant nymphaealean genera did not occur until the early Cenozoic (see Friis et al. 2011).

Nuphar has a geological history extending back to the Paleocene. Currently, there are no occurrences of the genus, extant or extinct, in the Southern Hemisphere, but the presence of its extinct relative, Notonuphar, in Antarctica during the Eocene indicates a much greater biogeographic range for Nuphar and its allies during the 
Paleogene and implies a post-Eocene extinction in the Southern Hemisphere. The earliest records of the genus include fossil seeds described as Nuphar cf. wutuensis I.Chen, Manchester \& Z.D.Chen from Paleocene deposits at the Almont locality, North Dakota (Chen et al. 2004) and Nuphar wutuensis I.Chen, Manchester \& Z.D.Chen from the early Eocene of the Shandong Province, China (Chen et al. 2004). Nuphar carlquistii DeVore, Witt Taylor \& Pigg is another early representative of Nuphar. It was described from latest early Eocene Republic flora of northcentral Washington, USA, and is documented by remains of fruits with seeds, attached stamens, scars from tepals and stamens, as well as isolated tepals co-occurring with rhizomes, root scars and a stigmatic disk also closely similar to those of extant Nuphar (Devore et al. 2015). Fossil seeds of Nuphar tastachensis P.I.Dorof. described from the Eocene of eastern Siberia represent another early member with external seed morphology very similar to Nuphar, but details of the seed coat are unknown (Dorofeev 1974) and the assignment to the extant genus is therefore not fully documented. Eight other fossil species assigned to Nuphar were reported from Oligocene to Pliocene sediments in Siberia and Europe (Dorofeev 1974). Among these are the seeds of Nuphar mazyrensis P.I.Dorof and Nuphar canaliculatum C.Reid \& E.Reid with high exotestal cells very similar to those of Brasenia and Notonuphar, but distinguished from those of Brasenia by the unfolded cell walls, and from Notonuphar in their uneven wall thickenings and conical lumina.

\section{Conclusion}

The fossil seeds of Notonuphar represent the first fossil record of Nymphaeales in Antarctica. Together with associated seeds of Nelumbo they also document for the first time the presence of extensive wetland habitats in the Eocene of the Antarctic Peninsula. The seeds were washed by rivers from their terrestrial habitat into the marine basin, where they were fossilized. Notonuphar is also the first record from the Southern Hemisphere of a nymphaealean plant closely related to the Northern Hemisphere genus Nuphar. Characters observed in Notonuphar support the transitional position of Nuphar between Cabombaceae and core Nymphaeaceae. The finding emphasizes the relictual distribution of living Nymphaeales.

\section{Taxonomic treatment}

Nymphaeales Dumort.

Nymphaeaceae Salisb.
Notonuphar E.M.Friis, A.Iglesias, Reguero \& Mörs, gen. nov. (extinct).-TYPE (designated here): Notonuphar antarctica E.M.Friis, A.Iglesias, Reguero \& Mörs, sp. nov.

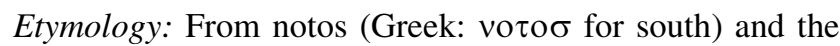
extant genus Nuphar to indicate close resemblance between the fossil Gondwanan seeds and those of extant Nuphar.

Generic and specific diagnosis: Seeds small, anatropous, bitegmic and exotestal, ovoid to ellipsoid, with rounded chalazal end and slightly pointed micropylar end. Lateral raphe indistinct on seed surface, distinct internally, extending in mesotesta from the hilar scar at the germination cap to the chalazal end of the seed. Germination cap with micropyle opening slightly raised and distinct shallow hilar scar close to micropyle. Micropyle and hilum separated by narrow zone of exotestal cells. Exotesta of one layer of high, palisade-shaped sclerenchyma cells with thick cell walls leaving a narrow, elongate lumen; anticlinal walls straight without undulations; facets on outer surface polygonal (pentagonal to hexagonal). Mesotesta of thin-walled parenchyma cells, few cell layers deep, thicker along the raphe and at chalazal and micropylar ends. Seed surface smooth with faint polygonal outlines of the exotestal cells.

Notes: The seeds of the new genus are closely similar to those of Nuphar (Nymphaeaceae), but are distinguished in having exotesta cells that are much taller and with much thicker cell walls. They also resemble seeds of Brasenia (Cabombaceae), but are distinguished in the straight, unfolded anticlinal walls of the exotestal cells and the presence of exotestal tissue between micropyle and hilum.

Nothonuphar antarctica E.M.Friis, A.Iglesias, Reguero \& Mörs, sp. nov.-HOLOTYPE (designated here): IAA 2/95, Marsupial site, Seymour Island, Antarctic Peninsula, $64^{\circ} 13^{\prime} 58^{\prime \prime} \mathrm{S} ; \quad 56^{\circ} 39^{\prime} 06^{\prime \prime} \mathrm{W}$ (S 174950) (Fig. 2a, d).PARATYPES (designated here): IAA 2/95, Marsupial site (S 174048, S 174049, S 174050-S 174058).

Etymology: From the continent where the fossil seeds were discovered.

Specific diagnosis: See combined generic and specific diagnosis.

Type horizon and age: Cucullaea I Allomember (Telm 5) of the La Meseta Formation, Eocene.

Additional specimens examined: Seymour Island IAA 1/90, Ungulate site, Seymour Island, Antarctic Peninsula, $64^{\circ} 14^{\prime} 04.67^{\prime \prime} \mathrm{S} ; \quad 56^{\circ} 39^{\prime} 56.38^{\prime \prime} \mathrm{W} \quad(\mathrm{S} 174003, \quad \mathrm{~S} 174046$, S 174047, S 174060-S 174066, S 174956; MLP 00-I-12a-MLP 00-I-1-2e). 
Acknowledgements We thank the Argentine Antarctic Institute (IAA-DNA) and the Argentine Air Force for logistical fieldwork support (to TM and MAR) and to the Swedish Polar Research Secretariat (SPFS) for logistical support (to TM). We also thank J. Moly for assistance in the field, M. de los Reyes (MLP) for screening and picking the fossils, F. Marone and A. Lindström for help with the SRXTM analyses performed at the Swiss Light Source, Paul Scherrer Institute, Villigen, Switzerland. Thanks are also due to the Servicio de Microscopia and the Instituto de Fisiología Vegetal (INFIVE) from La Plata University for technical assistance and Pollyanna von Knorring for preparing Fig. 1. Financial support from the Swedish Research Council (VR Grant 2009-4447 to TM. and Grant 2014-5228 to EMF), the Consejo Nacional de Investigaciones Científicas y Técnicas (CONICET Grant PIP 0462 to MAR.), the Argentine National Agency for Promotion of Science and Technology (ANPCyT Grant PICTO-2010-0093 to MAR) and the Paul Scherrer Institute https://www.psi.ch/useroffice/useroffice (projects 20130185, 20141047, 2016140) is gratefully acknowledged.

\section{Compliance with ethical standard}

Conflict of interest The authors declare that they have no conflict of interest.

Open Access This article is distributed under the terms of the Creative Commons Attribution 4.0 International License (http://crea tivecommons.org/licenses/by/4.0/), which permits unrestricted use, distribution, and reproduction in any medium, provided you give appropriate credit to the original author(s) and the source, provide a link to the Creative Commons license, and indicate if changes were made.

\section{References}

APG IV (2016) An update of the Angiosperm Phylogeny Group classification for the orders and families of flowering plants: APG IV. Bot J Linn Soc 181:1-20

Bomfleur B, Mörs T, Ferraguti M, Reguero MA, McLoughlin S (2015) Fossilized spermatozoa preserved in a 50-Myr-old annelid cocoon from Antarctica. Biol Lett 11:20150431. doi:10.1098/rsbl.2015.0431

Borsch T, Hilu KW, Wiersema JH, Löhne C, Barthlott W, Wilde V (2007) Phylogeny of Nymphaea (Nymphaeaceae): evidence from substitutions and microstructural changes in the chloroplast trnTtrnF region. Int J Pl Sci 168:639-671

Borsch T, Löhne C, Wiersema J (2008) Phylogeny and evolutionary patterns in Nymphaeales: integrating genes, genomes and morphology. Taxon 57:1052-1081

Cevallos-Ferriz SRS, Stockey RA (1989) Permineralized fruits and seeds from the Princeton Chert (middle Eocene) of British Columbia: Nymphaeaceae. Bot Gaz 150:207-217

Chen L, Manchester SR, Chen Z (2004) Anatomically preserved seeds of Nuphar (Nymphaeaceae) from the Early Eocene of Wutu, Shandong Province, China. Amer J Bot 91:1265-1272

Chornogubsky L, Goin FJ, Reguero M (2009) A reassessment of Antarctic polydolopid marsupials (Middle Eocene, La Meseta Formation). Antarctic Sci 21:285-297. doi:10.1017/S095410200 9001916

Coiffard C, Mohr BAR, Bernardes-De-Oliveira MEC (2013) Jaguariba wiersemana gen. nov. et sp. nov., an Early Cretaceous member of crown group Nymphaeales (Nymphaeaceae) from northern Gondwana. Taxon 62:141-151
Collinson ME (1980) Recent and Tertiary seeds of the Nymphaeaceae sensu lato with a revision of Brasenia ovula (Brong.) Reid and Chandler. Ann Bot (Oxford) 46:603-632

Devore ML, Taylor W, Pigg KB (2015) Nuphar carlquistii sp. nov. (Nymphaeaceae): a water lily from the latest early Eocene, Republic Washington. Int J Pl Sci 176:365-377. doi:10.1086/ 680482

Dorofeev PI (1972) To the taxonomy of the Euryale ancestral forms. Bot Zhurn (Moscow \& Leningrad) 57:1047-1054 (in Russian)

Dorofeev PI (1973) Systematics of ancestral forms of Brasenia. Paleontol J 7:219-227 (in Russian)

Dorofeev PI (1974) Nymphaeales. In: Takhtajan A (ed) Magnoliophyta fossila URSS. Nauka, Leningrad, pp 52-85 (in Russian)

Douglas PMJ, Affek HP, Ivany LC, Houben AJP, Sijp WP, Sluijs A, Schouten S, Pagani M (2014) Pronounced zonal heterogeneity in Eocene southern high-latitude sea surface temperatures. Proc Natl Acad Sci USA 111:6582-6587. doi:10.1073/pnas. 1321441111

Elliot DH (1988) Tectonic setting and evolution of the James Ross Basin, northern Antarctic Peninsula. Geol Soc Amer Mem 169:541-555

Engelbrecht A, Mörs T, Reguero M, Kriwet J (2016a) A new sawshark, Pristiophorus laevis, from the Eocene of Antarctica with comments on Pristiophorus lanceolatus. Hist Biol (First Online). doi:10.1080/08912963.2016.1252761

Engelbrecht A, Mörs T, Reguero M, Kriwet J (2016b) Revision of Eocene Antarctic carpet sharks (Elasmobranchii, Orectolobiformes) from Seymour Island, Antarctic Peninsula. J Syst Palaeontol (First Online). doi:10.1080/14772019.2016.1266048

Fassett NC (1953) A monograph of Cabomba. Castanea 18:116-128

Friis EM (1985) Angiosperm fruits and seeds from the Middle Miocene of Jutland (Denmark). Biol Skr Danske Vidensk Selsk 24:1-165

Friis EM, Pedersen KR, Crane PR (2001) Fossil evidence of water lilies (Nymphaeales) in the Early Cretaceous. Nature 410:357-360

Friis EM, Pedersen KR, von Balthazar M, Grimm GW, Crane PR (2009) Monetianthus mirus gen. et sp. nov., a nymphaealean flowers from the Early Cretaceous of Portugal. Int J Pl Sci 170:1086-1101. doi:10.1086/605120

Friis EM, Crane PR, Pedersen KR (2011) Early flowers and angiosperm evolution. Cambridge University Press, Cambridge

Friis EM, Marone F, Pedersen KR, Crane PR, Stampanoni M (2014) Three-dimensional visualization of fossil flowers, fruits, seeds and other plant remains using synchrotron radiation X-ray tomographic microscopy (SRXTM): New insights into Cretaceous plant diversity. J Paleontol 88:684-701. doi:10.1666/13099

Gee CT, Mörs T (2001) Aquatic macrophytes from the upper Oligocene fossillagerstätte of Rott (Rhineland, Germany). Part I: Seeds. Palaeontographica Abt B Paläophytol 259:33-45

Gelfo JN, Mörs T, Lorente M, López GM, Reguero M (2015) The oldest mammals from Antarctica, early Eocene of La Meseta Formation, Seymour Island. Palaeontology 58:101-110. doi:10. $1111 /$ pala. 12121

Iglesias A, Reguero M (2012) Semillas de angiospermas acuáticas del Eoceno temprano de Isla Seymour(=Marambio), Península Antártica. In: Leppe M, Aravena JC, Villa-Martínez R (eds) Abriendo Ventanas al Pasado, III Chilean Paleontological Symposium

Ivany LC, Lohmann KC, Blake DB, Aronson RB (2008) Eocene climate record of a high southern latitude continental shelf: Seymour Island, Antarctica. GSA Bulletin 120:659-678. doi:10. 1130/B26269.1

Kirchheimer F (1957) Die Laubgewächse der Braunkohlenzeit. Wilhelm Knapp Verlag, Halle 
Kriwet J (2005) Additions to the Eocene selachian fauna of Antarctica with comments on Antarctic selachian diversity. J Vertebr Paleontol 25:1-7. doi:10.1671/0272-4634(2005)025[0001: ATTESF]2.0.CO;2

Les DH, Schneider EL, Padgett DJ, Soltis PS, Soltis DE, Zanis M (1999) Phylogeny, classification and floral evolution of water lilies (Nymphaeaceae; Nymphaeales): a synthesis of nonmolecular, $r b c L$, matK, and rDNA data. Syst Bot 24:28-46

Löhne C, Yoo M-J, Borsch T, Wiersema J, Wilde V, Bell CD, Barthlott W, Soltis DE, Soltis PS (2008) Biogeography of nymphaeales: extant patterns and historical events. Taxon 57:1123-1146

Long DJ (1992) Sharks from the La Meseta formation (Eocene), Seymour Island, Antarctic Peninsula. J Vertebr Paleontol 12:11-32

Maddison WP, Maddison DR (2011) Mesquite: A modular system for evolutionary analysis. Version $2.75 \mathrm{http}: / /$ mesquiteproject.org

Mai DH (1964) Die Mastixioideen Floren im Tertiär der Oberlauzitz. Paläontol Abh Abt B Paläobot 2:1-192

Mai DH (1995) Tertiäre Vegetationsgeschichte Europas. Gustav Fischer Verlag, Jena, Stuttgart, New York

Marenssi SA (2006) Eustatically controlled sedimentation recorded by Eocene strata of the James Ross Basin, Antarctica. In: Francis JE, Pirrie D, Crame JA (eds) Cretaceous-Tertiary High-Latitude Palaeoenvironments, James Ross Basin, Antarctica. Geological Society, London, pp 125-133. doi:10.1144/GSL.SP.2006.258. 01.09

Marenssi SA, Santillana SN, Rinaldi CA (1998) Stratigraphy of the La Meseta Formation (Eocene), Marambio (Seymour) Island, Antarctica. In: Casadio S (ed) Paleógeno de América del Sur y de la Península Antártica, vol 5. Asociación Paleontológica Argentina, Publicación Especial, Buenos Aires, pp 137-146

Marenssi SA, Net LI, Santillana SN (2002) Provenance, depositional and paleogeographic controls on sandstone composition in an incised valley system: the Eocene La Meseta Formation, Seymour Island, Antarctica. Sediment Geol 150:301-321. doi:10.1016/S0037-0738(01)00201-9

McLoughlin S, Bomfleur B, Mörs T, Reguero MA (2016) Fossil clitellate annelid cocoons and their microbiological inclusions from the Eocene of Seymour Island, Antarctica. Palaeontologia Electronica 19.1.111A:1-27

Miki S (1960) Nymphaeaceous remains in Japan, with new fossil genus Eoeuryale. Inst Polytechn Osaka City Univ 11:63-78

Mohr BAR, Bernardes-De-Oliveira MEC, Taylor DW (2008) Pluricarpellatia, a nymphaealean angiosperm from the Lower Cretaceous of northern Gondwana (Crato Formation, Brazil). Taxon 57:1147-1158

Montes M, Nozal F, Santillana S, Marenssi S, Olivero E (2013) Mapa Geológico de la isla Marambio (Seymour) Escala 1:20.000, 1st edn. Serie Cartográfica Geocientífica Antáartica. Instituto Geológico y Minero de España, Madrid

Padgett DJ (2007) A monograph of Nuphar (Nymphaeaceae). Rhodora 109:1-95

Qiu Y-L, Lee J, Bernasconi-Quadroni F, Soltis DE, Soltis PS, Zanis M, Zimmer EA, Chen Z, Savolainen V, Chase MW (1999) The earliest angiosperms: evidence from mitochondrial, plastid and nuclear genomes. Nature 402:404-407

Rudall PJ, Sokoloff DD, Remizowa MV, Conran JG, Davis JI, Macfarlane TD, Stevenson DW (2007) Morphology of Hydatellaceae, an anomalous aquatic family recently recognized as an early-divergent angiosperm lineage. Amer J Bot 94:1073-1092

Sadler P (1988) Geometry and stratification of uppermost Cretaceous and Paleogene units of Seymour Island, northern Antarctic Peninsula. Geology and Paleontology of Seymour Island, Antarctic Peninsula. Feldmann RM and Woodburne MO Geol Soc Am Mem 169: 303-320

Schneider EL, Williamson PS (1993) Nymphaeaceae. In: Kubitzki K, Rohwer JG, Bittrich V (eds) The families and genera of vascular plants. II flowering plants-dicotyledons. Magnoliid, Hamamelid and Caryophyllid Families. Springer, Berlin, pp 486-493

Schwarzhans W, Mörs T, Engelbrecht A, Reguero M, Kriwet J (2016) Before the freeze: Otoliths from the Eocene of Seymour Island, Antarctica, reveal dominance of gadiform fishes (Teleostei). J Syst Palaeontol 15:147-170. doi:10.1080/14772019.2016.1151958

Stampanoni M, Groso A, Isenegger A, Mikuljan G, Chen Q, Bertrand A, Henein S, Betemps R, Frommherz U, Bohler P, Meister D, Lange M, Abela R (2006) Trends in synchrotron-based tomographic imaging: the SLS experience. In: Bonse U (ed) Developments in X-Ray Tomography V. Proc SPIE 6318:63180M. doi:10.1117/12.679497

Stilwell JD, Zinsmeister WJ (1992) Molluscan systematic and biostratigraphy. Lower tertiary la meseta formation, Seymour Island, Antarctic Peninsula, vol 55. Antarctic Research Series, America Geophysical Union, Washington DC, pp 1-192

Takahashi M, Crane PR, Friis EM (2007) Fossil seeds of Nymphaeales from the Tamayama Formation (Futaba Group), Upper Cretaceous (Early Santonian) of northeastern Honshu, Japan. Int J Pl Sci 168:341-350

Tambussi C, Acosta Hospitaleche C (2007) Antarctic birds (Neornithes) during the Cretaceous-Eocene times. Revista Asoc Geol Argent 64:604-617

Taylor DW, Gee CT (2014) Phylogenetic analysis of fossil water lilies based on leaf architecture vegetative characters: testing phylogenetic hypotheses from molecular studies. Bull Peabody Mus Nat Hist 55:89-110. doi:10.3374/014.055.0208

Taylor W, Devore ML, Pigg KB (2006) Susiea newsalemae gen. et sp. nov. (Nymphaeaceae): Euryale-like seeds from the Late Paleocene Almont Flora, North Dakota, USA. Int J Pl Sci 167:1271-1278

Taylor DW, Brenner GJ, Basha SH (2008) Scutifolium jordanicum gen. et sp. nov. (Cabombaceae), an aquatic fossil plant from the Lower Cretaceous of Jordan, and the relationships of related leaf fossils to living genera. Amer J Bot 95:340-352

Yamada T, Imaichi R, Kato M (2001) Developmental morphology of ovules and seeds of Nymphaeales. Amer J Bot 88:963-974

Yoo M-J, Bell CD, Soltis PS, Soltis DE (2005) Divergence times and historical biogeography of nymphaeales. Syst Bot 30:693-704 